\title{
Analisis Mutasi Gen Pancreatic Duodenal Homeobox 1 (PDX-1) Berdasarkan pada Kadar Glukosa Darah Kucing Domestik (Felis catus) Post Ovariohisterektomy
} (OH)

\section{The Analysis of Pancreatic Duodenal Homeobox 1 (PDX-1) Gene Mutation Based on Blood Glucose Level on Domestic Cats (Felis catus) Post Ovaryohisterectomy}

\author{
Hana Mitsuki Putri ${ }^{1}$, Aulanni’am ${ }^{1}$, Ajeng Aeka ${ }^{1}$, Dodik Prasetyo ${ }^{1}$, Fajar Shodiq Permata ${ }^{1}$ * \\ ${ }^{1}$ Fakultas Kedokteran Hewan Universitas Brawijaya \\ *Email : drh.fajar@ub.ac.id
}

\begin{abstract}
ABSTRAK
Ovariohisterectomy $(\mathrm{OH})$ pada kucing domestik menyebabkan beberapa efek samping, diantaranya yaitu obesitas. Obesitas berhubungan sangat erat dengan penyakit diabetes. Gen glukoregulator yang mungkin akan menjadi penyebab resistensi insulin jika mengalami mutasi gen adalah gen PDX-1. Resistensi insulin tersebut akan berpengaruh sangat erat dengan glukosa darah dalam tubuh. Tujuan penelitian adalah melihat hubungan antara polimorfisme gen PDX-1 dengan kadar glukosa darah pada kucing domestik yang mengalami $\mathrm{OH}$. Metode yang digunakan pada penelitian ini adalah amplifikasi invitro PCR gen PDX-1 dengan primer Forward 'CCG AGC TGT CAA AGC TAG CG' dan Reverse 'GAA CCG GTA GAG GGT CTT GG' dan dilanjutkan dengan sekuensing terhadap produk PCR. Hasil penelitian menunjukkan bahwa terdapat perbedaan mendasar pada urutan basa dalam sekuen gen PDX-1 pada c.435G >A, c.927A $>$ T, dan c.584A $>$ G. Perbedaan mendasar pada urutan gen PDX-1 merupakan silent mutation.
\end{abstract}

Kata Kunci : gen PDX-1, glukosa darah, kucing, mutasi gen, ovariohisterectomy.

\begin{abstract}
Ovariohysterectomy $(\mathrm{OH})$ in domestic cats causes several side effects, including obesity. Obesity is closely related to diabetes. The glucoregulatory gene that will cause insulin resistance if there is a gene mutation is the PDX-1 gene. This insulin resistance will have a very immediate effect on blood glucose in the body. The study examined the relationship between PDX-1 gene polymorphisms and blood glucose levels in domestic cats with $\mathrm{OH}$. The method used in this study was in vitro PCR amplification of the PDX-1 gene with Forward primers 'CCG AGC TGT CAA AGC TAG CG' and Reverse 'GAA CCG GTA GAG GGT CTT GG' and followed by sequencing of PCR products. The results showed fundamental differences in the base sequence in the PDX-1 gene sequences at c.435G>A, c.927A>T, and c.584A>G. The fundamental difference in the PDX1 gene sequence is a silent mutation.
\end{abstract}

Keywords : blood glucose, cat, gene mutation, ovariohisterectomy, PDX-1 gene

\section{PENDAHULUAN}

Jumlah populasi kucing di Indonesia sebesar 15 juta ekor, merupakan peringkat kedua sedunia (WSPA, 2007). Tingginya populasi kucing dapat meningkatkan risiko penyebaran penyakit baik kepada sesama bangsa kucing ataupun kepada manusia (Zoonosis). Pengendalian populasi kucing tersebut dapat dilakukan melalui tindakan medis ovariohysterectomy $(\mathrm{OH})$. Menurut WCPC (2009), ovariectomy adalah tindakan medis berupa amputasi, pengeluaran, dan pengangkatan ovarium dari dalam rongga abdomen. Sedangkan histerectomy merupakan tindakan 
amputasi, pengeluaran, dan pengambilan uterus dari dalam rongga abdomen (WCPC, 2009). Selain sebagai upaya menekan populasi kucing, $\mathrm{OH}$ dapat digunakan untuk indikasi medis seperti tumor uterus, pyometra, endometritis, kista, dan penyakit organ reproduksi lainnya (Bright, 2011). Pada sisi lain, tindakan $\mathrm{OH}$ menyebabkan meningkatnya risiko penyakit-penyakit seperti kanker tulang, displasia pinggul, obesitas, dan diabetes (Hardie, 2007).

Diabetes dapat terjadi ketika kadar insulin yang dihasilkan oleh kelenjar pankreas kurang dari kebutuhan untuk transport glukosa darah ke dalam sel. Diabetes pada kucing sangat mirip dengan diabetes tipe 2 pada manusia. Faktor risiko penyakit ini diantaranya adalah obesitas dan gaya hidup yang tidak aktif (Öhlund, 2017). Kucing yang telah disterilisasi memiliki dua hingga sembilan kali lipat peningkatan risiko terkena diabetes mellitus (Kustritz, 2012), diduga karena penurunan sensitivitas insulin. Penurunan sensitifitas insulin dapat disebabkan oleh obesitas, sehingga menyebabkan berkurangnya aktifitas fisik hewan.

Terjangkitnya penyakit diabetes dapat dipengaruhi oleh gen pembentukan insulin, salah satunya adalah Pancreatic Duodenal Homeobox 1 (PDX-1) yang merupakan gen faktor transkripsi yang berperan dalam proses terbentuknya pankreas pada masa organogenesis serta maturasi sel $\beta$ pankreas. Penurunan ekspresi gen PDX-1 menyebabkan kegagalan maturasi sel $\beta$ pankreas dan diabetes tipe 2. Defisiensi PDX-1 dapat menyebabkan disfungsi dan kematian sel $\beta$ pankreas yang menyebabkan penyakit diabetes. Kejadian ini dapat ditemui pada hewan pengerat maupun manusia (Fujimoto and Polonsky, 2009). Namun demikian, mutasi gen PDX-1 pada kucing belum pernah dilaporkan.

Penelitian ini bertujuan mendeteksi polimorfisme gen PDX-1 pada kucing dan menganalisis hubungan antara polimorfime gen PDX-1 dan peningkatan risiko penyakit diabetes pada kucing domestik (Felis catus) setelah dilakukan tindakan ovariohisterektomi.

\section{MATERI DAN METODE}

Penelitian dikerjakan di laboratorium Animal Disease Diagnostic, Fakultas Kedokteran Hewan Universitas Brawijaya. Sampel yang digunakan merupakan sampel darah dari tiga ekor kucing domestik pasca $\mathrm{OH}$ dan satu ekor kucing domestik belum $\mathrm{OH}$ yang telah dipuasakan selama 6 jam. Sampel darah diperoleh dari vena cephalica antebrachii sebanyak $1 \mathrm{~mL}$ menggunakan disposable syringe $1 \mathrm{~mL}$. Karakteristik sampel ditampilkan dalam Tabel 1. Pemeriksaan kadar glukosa dikerjakan di Laboratorium Klinik Panglima Sudirman, Malang.

Tabel 1. Sampel kucing domestik

\begin{tabular}{ccc}
\hline No & Kondisi & Kode \\
\hline 1 & $\mathrm{OH}$ & $\mathrm{KOH} 1$ \\
2 & $\mathrm{OH}$ & $\mathrm{KOH} 2$ \\
3 & $\mathrm{OH}$ & $\mathrm{KOH} 3$ \\
4 & $\mathrm{KNOH}$ & $\mathrm{KNOH}$ \\
\hline
\end{tabular}

\section{Isolasi DNA}

Isolasi DNA dilakukan menggunakan QiAmp DNA mini kit (Qiagen, Hilden, Germany). Darah dimasukkan ke dalam tabung eppendorf $1,5 \mathrm{~mL}$ dan 
ditambahkan $20 \mu \mathrm{L}$ protease, $300 \mu \mathrm{L}$ PBS dan $200 \mu \mathrm{L}$ buffer AL (Lysis buffer)., Kemudian campuran larutan dihomogenkan dengan vortex mixer selama 15 detik lalu diinkubasi 30 menit pada suhu $56^{\circ} \mathrm{C}$. Setelah diinkubasi, larutan ditambahkan $200 \quad \mu \mathrm{L}$ etanol absolut, kemudian divortex kembali 15 detik. Larutan kemudian dituangkan ke dalam spin collum yang terpasang pada collection tube dan disentrifuge selama satu menit pada 8.000 rpm. Spin collum dipindahkan pada collection tube baru, ditambah $500 \mu \mathrm{L}$ buffer AW1 dan disentrifuge selama satu menit pada 8.000 rpm. Setelah itu, sampel dipindahkan ke dalam collection tube baru, ditambah 500 $\mu \mathrm{L}$ buffer AW2 dan disentrifuge pada 13.500 rpm selama 6 menit. Setelah Spin collum dipindahkan dalam collection tube yang baru, ditambahkan $100 \mu \mathrm{L}$ buffer $\mathrm{AE}$, diamkan 1 menit dalam suhu ruang dan disentrifugasi pada $8.000 \mathrm{rpm}$ selama 1 menit.

\section{Uji Kuantitas DNA}

Pengujian kuantitas DNA dilakukan dengan alat berupa nanophotometer (AENano 200 Nucleic Acid Analyzer®, Pixel Lab Instrument Ltd., Guangdong, China) pada panjang gelombang $260 \mathrm{~nm}$, sedangkan pengukuran kemurnian DNA dikerjakan menggunakan panjang gelombang $260 \mathrm{~nm}$ dan $280 \mathrm{~nm}$ (Harahap, 2017). Batas nilai kemurnian DNA yang baik memiliki rasio 260/280 $\mathrm{nm}$ berkisar 1,7-2,0 dimana jika nilai absorbansi di luar batas normal dinyatakan bahwa adanya kontaminasi berlebih yang dapat mempengaruhi hasil pembacaan (Promega, 2017).

\section{Uji Kualitas DNA}

Uji kualitas DNA dilakukan terhadap hasil isolasi DNA total dengan elektroforensis menggunakan gel agarose untuk mengetahui panjang fragment DNA yang berhasil terisolasi. Elektroforesis (Biorad, CA, USA) dilakukan menggunakan gel agarose pada konsentrasi $1 \%$ yang dicampur EtBr $1 \mu \mathrm{L}$, pada tegangan 100 volt. DNA Ladder $1 \mathrm{~kb}$ ditambahkan pada satu kolom terpisah sebagai penanda (marker) ukurang panjang basa DNA. Gel agarose elektroforensis $1 \%$ kemudian divisualisasi menggunakan UV-Trasnsilluminator (BiO-Vision ${ }^{\mathrm{TM}}$, New York, USA).

\section{Desain Primer}

Primer didesain berdasarkan sekuen DNA dari Ensembl data base Gen dengan nomor akses ENSFCAT00000044231.2. (Ensembl, 2019). Primer forward diperoleh dari bagian awal exon 1 dan primer reverse diperoleh dari bagian awal intron 1-2, sehingga target gen yang didapatkan merupakan bagian dari exon 1 (578bp). Primer forward dan primer reverse didesain menggunakan perangkat lunak Primer 3 plus (primer3plus, A. Untergasser, Germany). Sepasang sekuens primer yang didapatkan adalah primer forward (HN_F) 5'- CCG AGC TGT CAA AGC TAG CG-3' (20 bp; Tm: 58, $5^{\circ} \mathrm{C}$; GC: $60,0 \%$ ) dan primer reverse (HN_R) 5'- GAA CCG GTA GAG GGT CTT GG -3' (length: 20 bp; Tm: $57,1^{\circ} \mathrm{C}$; GC: $60,0 \%)$.

Amplifikasi DNA PDX-1 dengan PCR berlangsung sebanyak 35 siklus, menggunakan alat Thermo Senso Quest (Hannah-vogt-str.1, Goettingen, 
Germany). Ukuran DNA target adalah 578 bp. Program PCR meliputi Pradenaturasi 4 menit pada $94^{\circ} \mathrm{C}$, denaturasi 30 detik pada $94^{\circ} \mathrm{C}$, annealing 30 detik pada $55,0^{\circ} \mathrm{C}$, eksistensi 1 menit pada $72^{\circ} \mathrm{C}$ dan post eksistensi 7 menit pada $72^{\circ} \mathrm{C}$ (Tabel 2). Sekuensing produk PCR 578 bp dikerjakan menggunakan metode Sanger sequencing (Sanger et al., 1977).

Tabel 2. Program PCR gen PDX-1

\begin{tabular}{ccc}
\hline Kondisi & Waktu & Suhu \\
\hline Pradenaturasi & 4 menit & $94^{\circ} \mathrm{C}$ \\
Denaturasi & 30 detik & $94^{\circ} \mathrm{C}$ \\
Annealing & 30 detik & $55,0^{\circ} \mathrm{C}$ \\
Eksistensi & 1 menit & $72^{\circ} \mathrm{C}$ \\
Post Eksistensi & 7 menit & $72^{\circ} \mathrm{C}$ \\
\hline
\end{tabular}

\section{Analisis Data}

Analisis obesitas dilakukan dengan perhitungan Feline Body Mass Indeks (FBMI) menggunakan metode Kawasumi dan Waltham (Waltham 2003; Kawasumi et al., 2016). Penghitungan dilakukan dengan membagi berat badan dengan panjang kaki belakang dari atas os. Patella hingga ujung os. Calcaneus (LIM atau Leg Index Measurement) dan dibandingkan dengan standar FBMI pada kedua metode tersebut.

Data sekuense DNA dianalisis secara kualitatif dengan mendeskripsikan perbedaan sekuen gen PDX-1 kucing domestik $\mathrm{OH}$ dan kucing domestik non $\mathrm{OH}$ serta menganalisa perbedaan sekuen asam amino menggunakan software BioEdit (BioEdit, sequence alignment editor) versi 7.2.5, (Informer Technologies Inc, Los Angeles, USA) dan BLAST NCBI. Tahapan analisis DNA dilakukan dengan penyejajaran sekuen
DNA. Skuen DNA yang digunakan berasal dari database Ensembl genome: ENSFCAT00000044231.2. menggunakan software BioEdit (Informer Technologies Inc, Los Angeles, USA)

\section{HASIL DAN PEMBAHASAN}

\section{Body Scoring Kucing}

Hasil pengukuran FBMI ditampilkan pada Tabel 3.

Tabel 3. Hasil pengukuran body scoring kucing menggunakan Feline Body Mass Index (FBMI)

\begin{tabular}{lcccc}
\hline Sampel & $\begin{array}{c}\text { Berat } \\
(\mathrm{kg})\end{array}$ & $\begin{array}{c}\text { LIM } \\
(\mathrm{cm})\end{array}$ & $\begin{array}{c}\text { Lingkar } \\
\text { Dada } \\
(\mathrm{cm})\end{array}$ & $\begin{array}{c}\text { Hasil } \\
\text { FBMI }\end{array}$ \\
\hline KOH1 & 4 & 15 & 34 & 26,6 \\
$\mathrm{KOH} 2$ & 4,5 & 12 & 38 & 37,5 \\
$\mathrm{KOH} 3$ & 3,5 & 15 & 31,5 & 23,3 \\
$\mathrm{KNOH}$ & 2 & 13 & 29 & 15,3 \\
\hline
\end{tabular}

Keterangan: $\mathrm{KOH} 1$ : Kucing $\mathrm{OH}$ 1, $\mathrm{KOH} 2$ : Kucing $\mathrm{OH}$ 2, KOH3: Kucing $\mathrm{OH} 3$, KNOH: Kucing Non $\mathrm{OH}$

Hasil pengukuran FBMI pada Tabel 3 menunjukkan satu kucing $\mathrm{OH}$ mengalami obesitas, sedangkan kucing lainnya normal Kawasumi et al., (2016). Sementara itu, berdasarkan kriteria yang dikembangkan oleh Waltham menunjukkan bahwa kucing tersebut mengalami kelebihan berat badan (overweight) (Waltham, 2003) (Gambar 1).

\section{Pemeriksaan Kadar Glukosa Darah Kucing}

Hasil pemeriksaan kadar glukosa pada kucing $\mathrm{OH}$ dan non $\mathrm{OH}$ ditampilkan pada Tabel 4. Seluruh kucing memiliki kadar glukosa dalam kisaran nilai normal. Dua kucing $\mathrm{OH}$ memiliki kadar glukosa 
normal tinggi, namun satu berada pada kadar yang rendah

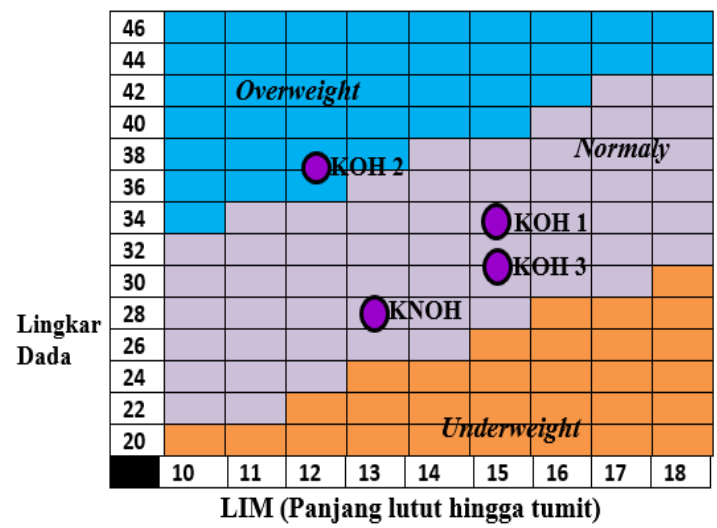

Gambar 1.Tabel Feline Body Mass Index (FBMI) metode Waltham (2003).

.Tabel 4. Kadar glukosa darah kucing

\begin{tabular}{|c|c|}
\hline Sampel & $\begin{array}{c}\text { Kadar Glukosa Darah } \\
(\mathrm{mg} / \mathrm{dL})\end{array}$ \\
\hline KOH1 & 159 \\
\hline $\mathrm{KOH} 2$ & 81 \\
\hline $\mathrm{KOH} 3$ & 157 \\
\hline $\mathrm{KNOH}$ & 103 \\
\hline Keterangan: & $\begin{array}{l}\text { KOH1: Kucing } \text { OH 1 } \\
\text { KOH2: Kyam), } \\
\text { KOH3: Kucing OH } 3 \text { (MJ), KNOH: } \\
\text { Kucing Non OH (Bodo) }\end{array}$ \\
\hline
\end{tabular}

Selain diabetes, stres akut dapat mengakibatkan hiperglikemia (Nelson, 2002), Kadar gula darah akibat stres akut dapat meningkat mencapai 300-400 $\mathrm{mg} / \mathrm{dL}$ (Behrend et al., 2018). Faktor lain yang meningkatkan kadar glukosa darah adalah keadaan hemolysis (Koseoglu et al., 2010).

\section{Uji Kuantitas dan Kualitas Hasil Isolasi DNA Darah Kucing Domestik Post OH}

Hasil nilai konsentrasi dan kemurnian uji kuantitas DNA ditampilkan dalam Tabel 5, dimana hasil uji kuantitas sampel KOH1 menunjukkan konsentrasi DNA sebesar 5,42 $\mathrm{ng} / \mu \mathrm{L}$, sampel $\mathrm{KOH} 2$ sebesar 5,80 ng/ $\mu \mathrm{L}$, sampel $\mathrm{KOH} 3$ sebesar 3,31 ng/ $\mu \mathrm{L}$, dan pada $\mathrm{KNOH}$ sebesar 28,67 ng/ $\mathrm{LL}$.

Tabel 5. Konsentrasi dan kemurnian kucing domestik (Felis catus)

\begin{tabular}{ccc}
\hline Kode Sampel & $\begin{array}{c}\text { Konsentrasi } \\
(\mathrm{ng} / \mu \mathrm{L})\end{array}$ & $\begin{array}{c}\text { Kemurnian } \\
(\mathrm{nm}) \\
\left(\begin{array}{c}\text { Absorbansi } \\
260 / 280)\end{array}\right.\end{array}$ \\
\hline $\mathrm{KOH} 1$ & 5,42 & 1,98 \\
\hline $\mathrm{KOH} 2$ & 5,80 & 8,48 \\
\hline $\mathrm{KOH} 3$ & 3,31 & 3,71 \\
\hline $\mathrm{KNOH}$ & 28,67 & 1,68 \\
\hline
\end{tabular}

Uji kemurnian DNA total didapatkan hasil yang ditujukkan pada sampel $\mathrm{KOH} 1$ mendapatkan nilai kemurnian yang baik yaitu 1,98. Sampel $\mathrm{KOH} 2$ dan $\mathrm{KOH} 3$ menunjukkan nilai diatas 2,0, sedangkan pada sampel $\mathrm{KNOH}$ menunjukkan nilai dibawah 1,7. Menurut Santella (2006), jika rasio tersebut berada di atas kisaran nilai normal DNA murni maka terjadi kontaminasi RNA, sedangkan rasio di bawah 1,7 maka ditemukan adanya kontaminasi protein. Walaupun tiga sampel DNA menunjukkan hasil di luar batas nilai normal namun amplifikasi dengan PCR tetap dapat dilakukan, karena kontaminan tidak menghambat aktivitas kerja yang dimiliki oleh enzim polymerase (Chen and Janes, 2002).

\section{Amplifikasi Gen PDX-1 dengan Metode PCR}

Hasil elektroforesis ditunjukkan pada Gambar 3. Produk PCR gen PDX-1 berukuran 578 bp. 
Putri dkk : Analisis Mutasi Gen Pancreatic Duodenal Homeobox 1 (PDX-1) Berdasarkan pada Kadar Glukosa Darah Kucing Domestik (Felis catus) Post Ovariohisterektomy $(\mathrm{OH})$

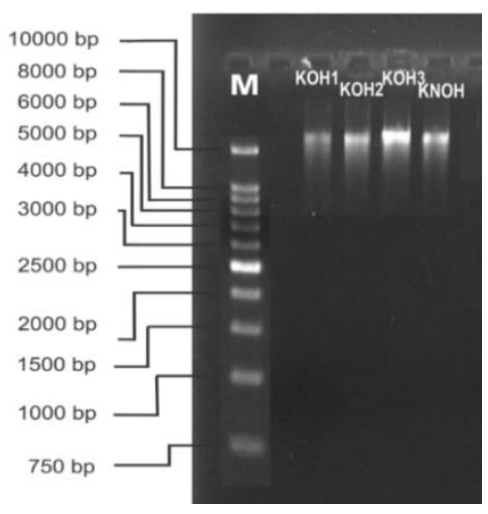

Gambar 2. Elektroforensis DNA total (agarose $1 \%$ )

Keterangan : M : Marker (1 kb), $\mathrm{KOH}$ (Kucing Ovarihisterektomi), $\mathrm{KNOH} \quad$ (Kucing non Ovariohisterektomi), KOH1: Ayam, KOH2: Mui, KOH3: MJ,KNOH: Bodo

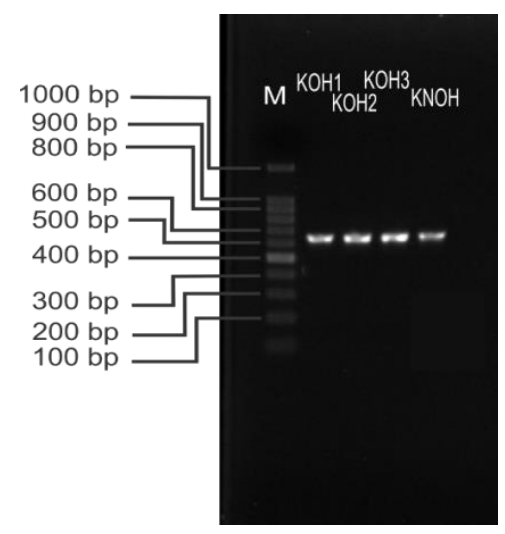

Gambar 3. Hasil elektroforensis produk PCR konsentrasi agarose $1,8 \%$. Keterangan : M: Marker (100bp), KOH1: Ayam, KOH2: Mui, KOH3: MJ, KNOH: Bodo.

\section{Sekuensing Gen PDX-1 Kucing Domestik}

Sekuens sampel KOH1 memiliki grafik elektroferogram yang kurang baik. Hal ini menyebabkan sampel KOH1 tidak dapat digunakan untuk proses analisis selanjutnya yaitu penyejajaran sekuens DNA. Sampel $\mathrm{KOH} 2, \quad \mathrm{KOH} 3$ disejajarkan dengan $\mathrm{KNOH}$ dengan gen
PDX-1 dari sekuens DNA kromosom A1 Felis catus urutan 7559071-7566360.

Tabel 6. Query Coverage dan Identity sampel dibandingkan dengan database genebank DNA PDX-1 kucing dengan kode akses NCBI Genebank: XM 011281516.2 .

\begin{tabular}{ccc}
\hline Sampel & $\begin{array}{c}\text { Query } \\
\text { Coverage }\end{array}$ & Identity \\
\hline $\mathrm{KOH} 2$ & $85 \%$ & $99 \%$ \\
$\mathrm{KOH} 3$ & $85 \%$ & $99 \%$ \\
$\mathrm{KNOH}$ & $85 \%$ & $99 \%$ \\
\hline
\end{tabular}

Pada Tabel 6, sampel kucing domestik $\mathrm{KOH} 2, \mathrm{KOH} 3$, dan $\mathrm{KNOH}$ memiliki nilai query coverage $85 \%$ dan identity $99 \%$ jika dibandingkan dengan DNA PDX-1 kucing dengan kode akses NCBI Genebank: XM 011281516.2. Persentase nilai query coverage menunjukkan persen panjang dari segmen DNA yang dilakukan pensejajaran. Nilai identity menunjukkan presentasi dari identitas dari satu segmen DNA. Hasil pensejajaran menunjukkan bahwa sekuen DNA sampel $\mathrm{KOH} 2, \mathrm{KOH} 3$, dan $\mathrm{KNOH}$ memiliki kemiripan dengan sekuen DNA yang diinginkan yaitu gen PDX-1 kucing domestik.

\section{Analisa Sekuens DNA dan Asam Amino Gen PDX-1 Kucing Domestik OH}

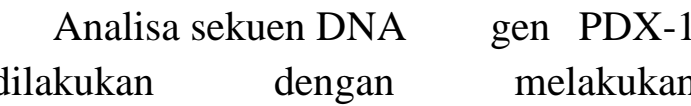
penyejajaran sekuen DNA sampel $\mathrm{KOH} 2$, $\mathrm{KOH} 3$, dan $\mathrm{KNOH}$ serta database gen PDX-1 Ensembl genome: ENSFCAT00000044231.2 Urutan sekuen sampel yang disejajarkan dimulai dari basa 401 sampai 927 dengan total target gen yaitu $526 \mathrm{bp}$. 
Tabel 7. Mutasi pada ketiga sekuen sampel dibandingkan dengan database Genebank

\begin{tabular}{cccc}
\multicolumn{4}{c}{ Genebank } \\
Sampel & Letak Basa & Substitusi & $\begin{array}{c}\text { Jenis } \\
\text { Mutasi }\end{array}$ \\
\hline \multirow{3}{*}{ KOH2 } & 435 & G $>$ A & Transversi \\
& 927 & A $>$ T & Transisi \\
& 584 & G $>$ A & Transversi \\
KOH3 & 435 & G $>$ A & Transversi \\
& 927 & A $>$ T & Transisi \\
KNOH & 435 & G $>$ A & Transversi \\
& 927 & A $>$ T & Transisi \\
\hline
\end{tabular}

Berdasarkan Tabel 7, terdapat dua mutasi transversi $\mathrm{G}>\mathrm{A}$ pada sampel $\mathrm{KOH} 2$ yaitu pada basa ke 435 dan 584 dan satu mutasi transversi pada $\mathrm{KOH} 3$ dan $\mathrm{KNOH}$ pada basa ke 435. Terdapat mutasi transisi $\mathrm{A}>\mathrm{T}$ pada basa ke 927 pada $\mathrm{KOH} 2, \mathrm{KOH} 3$ dan $\mathrm{KNOH}$. Transversi merupakan bergantinya basa purin dengan pirimidin, primidin dengan purin pada posisi yang sama, sedangkan transisi merupakan bergantinya basa pada purin dengan purin ataupun pirimidin dengan pirimidin (Warmadewi, 2017).

Analisa sekuen asam amino dilakukan dengan cara menerjemahkan sekuen gen bagian exon 1 gen PDX-1 dengan BLASTx. Hal ini bertujuan untuk menerjemahkan sekuen gen menjadi sekuen asam amino dan disejajarkan dengan database protein PDX-1 NCBI.

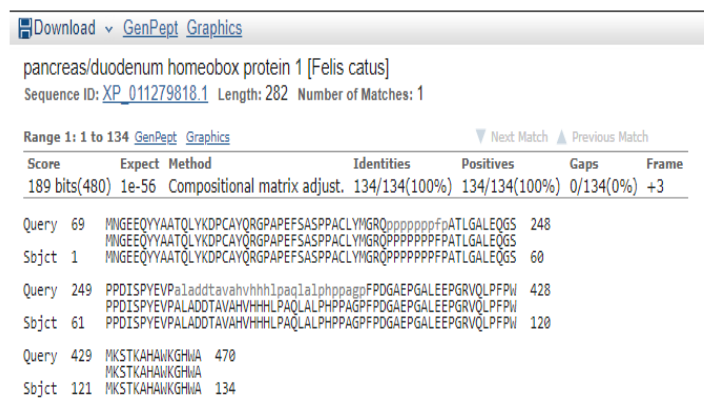

Gambar 4. Hasil BLAST sekuen asam amino gen PDX-1
Hasil BLASTx sekuen asam amino ketiga sampel ditunjukkan pada Gambar 4. Asam amino mulai terekspresi dari basa ke 69 hingga 470. Sekuen asam amino sampel apabila dibandingkan dengan sekuen asam amino database NCBI memiliki nilai identity $100 \%$. Hal ini mengindikasikan bahwa perubahan urutan sekuen DNA gen PDX-1 pada sampel $\mathrm{KOH} 2, \mathrm{KOH} 3$, dan $\mathrm{KNOH}$ merupakan silent mutation (Warianto, 2011). Silent mutation adalah mutasi yang hanya terjadi pada genotif gen tapi tidak merubah ekspresi gen. Terjadinya perbedaan sekuen basa gen PDX-1 kucing domestik merupakan polimorfisme (Indrawan et al., 2007). Polimorfisme disebabkan oleh faktor keturunan ataupun faktor lingkungan (tidak diwariskan) (Laimeheriwa, 2018).

\section{Hubungan Gen PDX-1 dengan Obesitas pada Kucing}

Gen PDX-1 merupakan gen glukoregulator tubuh yang secara tidak langsung berperan dalam pengaturan kadar glukosa darah. Polimorfisme gen PDX-1 diduga merupakan salah satu faktor yang hubungan dengan kejadian diabetes melitus tipe 2. Dalam penelitian ini, pada kucing $\mathrm{OH}$ yang mengalami obesitas $(\mathrm{KOH} 2)$ ditemukan lebih banyak silent mutation pada gen PDX-1 dibandingkan dengan kucing $\mathrm{OH}$ yang tidak mengalami obesitas $(\mathrm{KOH} 3)$ atau kucing non $\mathrm{OH}$ yang tidak mengalami obesitas $(\mathrm{KNOH})$. Walaupun penelitian ini tidak dapat menyimpulkan peran gen PDX-1 pada obesitas kucing domestik $\mathrm{OH}$ karena jumlah sampel yang terbatas, tapi penelitian ini dapat menjadi dasar studi lanjutan dengan sampel yang lebih 
banyak, untuk mengetahui peran gen PDX-1 dalam obesitas kucing pasca operasi $\mathrm{OH}$.

Penyebab lain diabetes melitus akibat resistensi insulin adalah polimorfisme pada gen fosforilasi tyrosine reseptor insulin dan pada protein IRS yang menyebabkan abnormalitas dari fungsi reseptor GLUT4 (Wilcox, 2005; Sheperd and Kahn, 1999). Riset lanjutan tentang faktor risiko genetik diabetes melitus pada kucing $\mathrm{OH}$ dapat diarahkan pada analisis tentang peran gen-gen ini.

\section{KESIMPULAN}

Terjadi dua mutasi transversi dan satu mutasi transisi pada gen PDX-1 dengan terjadi perubahan c.435G $>$ A, c.927A $>$ T, dan c.584G $>$ A namun merupakan silent mutation.

\section{DAFTAR PUSTAKA}

Behrend, E., Holford, A., Lathan, P., Rucinsky, R., Schulman, R. 2018. 2018 AAHA Diabetes Management Guidelines for Dogs and Cats. Journal of the American Animal Hospital Association. 54(1):1-21.

Bright, R. M. 2011. Sterilization of Female Cats. Saunders: Elsevier. Inc.

Chen, B. Y. and Janes, H. W. 2002. Methods in Biomolecular Biology. PCR Cloning Protocols. Ed ke-2. Rutgers University.

Ensembl. 2019.

Gene: ENSFCAG00000044231. [diunduh 2019 Agu 27]. Tersedia pada: https://asia.ensembl.org/Felis_catus/T ranscript/Summary? $\mathrm{db}=$ core; $\mathrm{g}=\mathrm{ENSF}$ CAG00000044231;r=E2:5373593853820705;t=ENSFCAT00000056838
Fujimoto, K. and Polonsky, K. S. 2009. $\mathrm{Pdx} 1$ and other factors that regulate pancreatic $\beta$-cell survival. Diabetes, Obesity and Metabolism. 11:30-37.

Harahap, A. S. 2017. Uji Kualitas dan Kuantitas DNA Beberapa Populasi Pohon Kapur Sumatera. Journal of Science and Agronomy Panca Budi. 2(2):1-6.

Hardie, E. 2007. Pros and Cons of Neutering. New York: International Veterinary Information Service.

Indrawan, M., Primack, R. B., Supriatna, J. 2007. Biologi: Konservasi. Jakarta: Yayasan Obor Indonesia.

Kawasumi, K., Iwazaki, E., Okada, Y., Arai, T. 2016. Effectiveness of feline body mass index (fBMI) as new diagnostic tool for obesity. Japanese Journal of Veterinary Research. 64(1):51-55.

Koseoglu, M., Hur, A., Atay, A., Çuhadar, S. 2010. Original professional article. Biochemia Medica. 2(1):79-85.

Kustritz, M. V. 2012. Effects of Surgical Sterilization on Canine and Feline Health and on Society. Minnesota: Blackwell Verlag GmbH.

Laimeheriwa, B. M. 2018. Mekanisme Terjadinya Variasi Individu dalam Populasinya. Universitas Pattimura.

Nelson, R. 2002. Editorial: Stress Hyperglycemia and Diabetes Mellitus in Cats. Journal of Veterinary Internal Medicine. 16(2):121-122.

Öhlund, M. 2017. Feline diabetes mellitus: Aspects on epidemiology and pathogenesis. Uppsala: Faculty of Veterinary Medicine and Animal 
Putri dkk : Analisis Mutasi Gen Pancreatic Duodenal Homeobox 1 (PDX-1) Berdasarkan pada Kadar Glukosa Darah Kucing Domestik (Felis catus) Post Ovariohisterektomy $(\mathrm{OH})$

Science Department of Clinical Sciences.

Promega. 2017. How I Determine the concentration, yield and purity of a DNA sample. [diunduh 2019 Mei 15]. Tersedia pada: https://worldwide. promega.com/resources/pubhub/enote s/how-do-i-determine-theconcentration-yield-and-purity-of-aDNA-sample/? activeTab $=0$

Sanger, F., Nicklen, S., Coulson, A. R. 1977. DNA sequencing with chainterminating inhibitors. Proceedings of the National Academy of Sciences. 74(12):5463-5467.

Santella, R. M. 2006. Approaches to DNA/RNA Extraction and Whole Genome Amplification. Cancer Epidemiol Biomarkers.

Sheperd, P. R. and Kahn, B. B. 1999. Glucose Transporter and Insulin Action. The New England Journal of Medicine.

Waltham. 2003. Feline Body Mass Index (FBMI). Clinic Tools.

Warianto, C. 2011. Mutasi Handout Kuliah.

Warmadewi, D. A. 2017. Buku Ajar Mutasi Genetik. Denpasar: Universitas Udayana.

WCPC. 2009. Ovariohysterectomy in Cats. [diunduh 2018 Okt 13]. Tersedia pada: ://www. willowcreekpet.com/wpcontent/uploa ds/Ovariohysterectomy-in-Cats.pdf

Wilcox, G. 2005. Insulin and Insulin Resistance. Clin Biochemicsl Review. 26(2):19-39.
WSPA. 2007. Global Companion Animal Ownership and Trade: Project Summary. [diunduh 2018 Okt 13]. Tersedia pada: http://www. wspainternational.org 